\title{
ZASTOSOWANIE MIĘDZYNARODOWYCH INDEKSÓW DO OCENY INNOWACYJNOŚCI GOSPODAREK UNII EUROPEJSKIEJ
}

\begin{abstract}
(Streszczenie)
Przemiany w gospodarce światowej ostatnich lat wskazują na odchodzenie od industrializmu na rzecz gospodarki wiedzochłonnej opierającej się na zaawansowanym poziomie kapitału ludzkiego oraz potencjale technologicznym. W dobie powszechnego wykorzystania technologii teleinformatycznych wiedzę cechuje wzmożona intensywność zmian, rosnące wykorzystanie praktyczne oraz szybkość i łatwość dostępu. Człowiek, przedsiębiorstwo, ale i gospodarka muszą adaptować się do tych zmian, bo to jest gwarantem dalszego postępu. Celem artykułu jest pogłębiona interpretacja poziomu innowacyjności krajów Unii Europejskiej z perspektywy międzynarodowych rankingów ze szczególnym uwzględnieniem sfery badawczo-rozwojowej. Praca składa się z czterech części. Tuż po części wprowadzającej, w punkcie drugim wyjaśnione zostały podstawowe pojęcia teoretyczne, istotne z punktu widzenia poruszanego w artykule tematu. W kolejnej, trzeciej części pokazana została klasyfikacja państw należących do struktur unijnych w międzynarodowych rankingach innowacyjności, w szczególności w Innovation Union Scoreboard (IUS). W tej części opracowania zaprezentowano również analizę empiryczną przeprowadzoną w oparciu o dane statystyczne zawarte w raportach międzynarodowych oraz dostępne w bazie Eurostat. Ostatnia część artykułu to podsumowanie przeprowadzonego wywodu teoretyczno-empirycznego. Materiał statystyczny prezentowany w kolejnych częściach artykułu pracy pochodzi z Urzędu Statystycznego UE (Eurostatu), Banku Światowego oraz poszczególnych badań nad innowacyjnością (IUS, EIS, GII). Z przeprowadzonych rozważań wynika, że poprawa innowacyjności gospodarek narodowych wymaga większego zaangażowania sektora prywatnego w finansowanie działalności badawczo-rozwojowej.
\end{abstract}

* Dr hab., prof. nadzw. UŁ, Uniwersytet Łódzki, Katedra Statystyki Ekonomicznej i Społecznej; e-mail:mgrzel@wp.p

** Dr, Uniwersytet Łódzki, Katedra Statystyki Ekonomicznej i Społecznej; e-mail: eroszko33@ gmail.com 
Wprawdzie w ostatnich latach zaobserwowano pozytywne zmiany w tym zakresie w większości krajów UE, ale nadal skala tych zmian nie jest wystarczająca wobec zapotrzebowania rynku.

Slowa kluczowe: innowacyjność; Unia Europejska; Summary Innovation Index; Global Innovation Index; miernik syntetyczny

Klasyfikacja JEL: O30

\section{Wstęp}

Na przestrzeni ostatnich lat pojęcie innowacji oraz innowacyjności cieszy się niesłabnącym zainteresowaniem zarówno teoretyków, jak i praktyków. Rozumienie innowacji może odbywać się w szerokim i wąskim zakresie. W zawężonym aspekcie przyjmuje się tylko i wyłącznie nowości wprowadzone po raz pierwszy na rynek, które ograniczają się zwykle do innowacji technicznych mających wpływ na procesy produkcji. W szerokim ujęciu termin ten może być utożsamiany z każdą sferą życia. Wyników działalności innowacyjnej można upatrywać zarówno w praktyce gospodarczej, systemach społecznych, ale również w strukturach organizacyjnych oraz rozwiązaniach marketingowych.

Przemiany w gospodarce światowej ostatnich lat wskazują na odchodzenie od industrializmu na rzecz gospodarki wiedzochłonnej opierającej się na zaawansowanym poziomie kapitału ludzkiego oraz potencjale technologicznym. Zapotrzebowanie na pracę przesuwa się ze sfery robotników produkcyjnych w kierunku ludzi kreatywnych, tworzących patenty, zgłaszających nowe pomysły i teorie naukowe, a dodatkowo mających zmysł organizacyjny ${ }^{1}$. W dobie powszechnego wykorzystania technologii teleinformatycznych wiedzę cechuje wzmożona intensywność zmian, rosnące wykorzystanie praktyczne oraz szybkość i łatwość dostępu. Potrzeba ciagłego pogłębiania wiedzy to aktualnie nieodłączny element życia człowieka. Człowiek, przedsiębiorstwo, ale i gospodarka muszą adaptować się do tych zmian, bo to jest gwarantem dalszego postępu. Większego znaczenia nabierają czynniki niematerialne - to one przyczyniają się do kreowania konkurencji. Co więcej, rozwój technologiczny i globalizacja gospodarki wzmagają konkurencję na arenie międzynarodowej. Powstające nowości technologiczne i ich rozpowszechnianie nie tylko oddziałują na wzrost efektywności działalności ekonomicznej, ale też zmieniają gospodarkę poprzez między innymi

\footnotetext{
A. Toffler, Trzecia fala, PIW, Warszawa 1985, s. 229, 436-437; K. Beyer, Funkcjonowanie przedsiębiorstw w gospodarce opartej na wiedzy, w: Nierówności społeczne a wzrost gospodarczy, z. 35, Wydawnictwo Uniwersytetu Rzeszowskiego, Rzeszów 2013, s. 52-53.
} 
tworzenie nowych usług i produktów ${ }^{2}$. W kreowaniu innowacji ważna jest rola nauki i techniki. Wiedza techniczna zdaje się być niezbędna do tworzenia nowych technologii. Co za tym idzie poziom wykształcenia i poziom techniczny stają się aktualnie głównym motorem w rozwoju gospodarczo-społecznym. Szczególnego znaczenia nabiera również mobilność wiedzy i możliwość szybkiego transferu różnego rodzaju technologii oraz zasobów ludzkich.

Celem artykułu jest pogłębiona interpretacja poziomu innowacyjności krajów Unii Europejskiej z perspektywy międzynarodowych rankingów ze szczególnym uwzględnieniem sfery badawczo-rozwojowej.

Praca składa się z czterech części. Tuż po części wprowadzającej, w punkcie drugim zostały przedstawione powiązania pomiędzy nauką i techniką a rozwojem społeczno-gospodarczym oraz wyjaśnione podstawowe pojęcia teoretyczne, istotne z punktu widzenia poruszanego w artykule tematu. W kolejnej, trzeciej części pokazana została klasyfikacja państw należących do struktur unijnych w międzynarodowych rankingach innowacyjności, w szczególności w Innovation Union Scoreboard (IUS). Punkt ten przybliża kluczowe aspekty metodologiczne i genezę wybranych wskaźników syntetycznych, europejskiego - Summary Innovation Index oraz ogólnoświatowego - Global Innovation Index. W tej części opracowania zaprezentowano również analizę empiryczną przeprowadzoną w oparciu o dane statystyczne zawarte w raportach międzynarodowych oraz dostępne w bazie Eurostat. Ostatni punkt artykułu to podsumowanie przeprowadzonego wywodu teoretyczno-empirycznego.

Źródła wykorzystane w części teoretycznej pochodzą zarówno z publikacji książkowych, raportów tematycznych, jak i artykułów. Materiał statystyczny prezentowany w kolejnych punktach pracy bazuje na danych zaczerpniętych z Urzędu Statystycznego UE (Eurostat), Banku Światowego oraz poszczególnych badań nad innowacyjnością (IUS, EIS, GII).

\section{Rola nauki i techniki w rozwoju społeczno-gospodarczym}

Współcześnie innowacje stanowią ważny element rzeczywistości społecznej i gospodarczej. Przynoszą korzyści wszystkim obywatelom, zarówno pracownikom, jak i pracodawcom, konsumentom i producentom. Definicja innowacji została po raz pierwszy przedstawiona w roku 1912 przez austriackiego ekono-

J. Woroniecki, Nowa gospodarka: miraż czy rzeczywistość? Doktryna - Praktyka - Optyka $O E C D$, w: W. Welfe (red.), Społeczeństwo oparte na wiedzy, Społeczna Wyższa Szkoła Przedsiębiorczości i Zarządzania w Łodzi, Łódź 2001, s. 33. 
mistę Josepha Schumpetera. Zakładała ona, że innowacja to (obok przedsiębiorczości i kredytu) główny czynnik wzrostu gospodarczego wzrostu i rozwoju Schumpeter pojmował innowacje jako wprowadzenie nowego procesu przez przedsiębiorcę motywowanego zyskiem bądź komercjalizacją nowego produktu. W efekcie za główną siłę rozwoju można uznać przedsiębiorczość. Christopher Freeman, brytyjski ekonomista, uczeń schumpeteriańskiej szkoły, twierdził, iż innowacją jest pierwsze komercyjne wprowadzenie nowego procesu, produktu, systemu czy też urządzenia ${ }^{4}$. Pogląd ten podzielał Edwin Mansfield, amerykański uczony, dla którego innowacją było pierwsze zastosowanie wynalazku. Wprowadzenie różnicy pomiędzy wynalazkiem a innowacją było ważnym osiągnięciem Schumpetera. Według niego kreowanie wiedzy (wynalazek) jest diametralnie inne niż wprowadzenie wiedzy do produkcji (innowacja). Jest to ważne, gdyż szereg wynalazków nigdy nie znajduje zastosowania, ergo nie prowadzi do innowacji, natomiast $\mathrm{z}$ drugiej strony wiele innowacji nie wymaga wynalazkus. Peter F. Drucker wskazał istotność oraz znaczenie innowacji w działalności gospodarczej podmiotów. Uznał innowację za podstawową i główną siłą napędową przedsiębiorczości. Dzięki racjonalnej i zorganizowanej pracy innowacja nadaje z pozoru bezcelowym zasobom nowe perspektywy kreowania bogactwa. Ponadto, Drucker wysuną 3 twierdzenia odnośnie do innowacji6:

- innowacja wymaga wiedzy, nierzadko ogromnej inwencji oraz odpowiednich predyspozycji, jednakże nade wszystko oznacza ciężka, przemyślaną pracę;

- w celu odniesienia sukcesu innowatorzy powinni bazować na swych mocnych stronach i wielozakresowo patrzeć na możliwości;

- innowacja to skutek procesów gospodarczo-społecznych, zmiana w produkcji, pracy i postępowaniu ludzi.

Drucker, komentując twórczość Schumpetera jako jedynego wybitnego ekonomisty, który podjął się tematu wpływu wywieranego przez przedsiębiorców na gospodarkę ${ }^{7}$, pisał, iż „normą zdrowej gospodarki i centralną kwestią dla teorii i praktyki ekonomicznej powinna być dynamiczna nierównowaga wywoływana przez wprowadzającego innowację przedsiębiorcę, a nie równowaga i optyma-

J.A. Schumpeter, Teoria rozwoju gospodarczego, PWN, Warszawa 1960, s. 103-104.

Ch. Freeman, The Economics of Industrial Innovation, F. Pinter, London 1982.

M.M. Grzelak, Innowacyjność przemystu spożywczego w Polsce. Ocena. Uwarunkowania. Rozwój, Wydawnictwo Uniwersytetu Łódzkiego, Łódź 2011, s. 18.

6 P.F. Drucker, Natchnienie i fart, czyli innowacje i przedsiębiorczość, Studio Emka, Warszawa 2004, s. 161.

7 P.F. Drucker, Innovation and Entrepreurship, Harper and Row, New York 1985, s. 13, za: S. Kwiatkowski, Społeczeństwo innowacyjne, PWN, Warszawa 1990, s. 14. 
lizacja"8. To pozwala stwierdzić, iż gospodarka jest w równowadze tylko przejściowo. Wytrącanie jej z tej ,równowagi” przez chciwych przedsiębiorców jest jedyną szansą na rozwój systemu gospodarczego. Burzenie równowagi lub, jak to nazwał Schumpeter w 1942 r., ,twórcza destrukcja” jest najefektywniejszym wykorzystaniem zasobów i zmierzaniem ku postępowi.

Ograniczony dostęp do czynników produkcji, zarówno naturalnych, jak i siły roboczej, oraz rosnące koszty zastosowania tworzyw sztucznych determinują potrzebę ciagłej poprawy wydajności pracy. Wprowadzanie nowych pomysłów i technik to nie tylko konieczność wynikająca z potrzeby utrzymania kosztów wytworzenia na zadowalającym poziomie, to również, jeśli nie przede wszystkim, siła napędowa postępu gospodarczego 9 . Zapewnienie odpowiedniego standardu życia jak najliczniejszej społeczności to dążenie obecnych rządów. Polityka gospodarcza, w tym polityka innowacyjna, skupia się na poprawie bytu ludności i stwarzaniu sprzyjających warunków dla rozwoju rodzimej przedsiębiorczości. Polityka krajowa staje przed prawdziwym wyzwaniem, jakim jest szersze włączenie społeczne, większe zaangażowanie MŚP $\mathrm{w}$ sferę $\mathrm{B}+\mathrm{R}$, poprawa dostępu do odpowiednich instrumentów finansowych, wspieranie sektora zamówień publicznych w zakresie innowacji, ułatwianie współpracy nauki i biznesu, wspieranie badań nad innowacjami, w tym innowacjami społecznymi, w sektorze publicznym i prywatnym ${ }^{10}$. Rośnie, w związku z tym, rola i znaczenie badań naukowych, szczególnie w krajach dążących do poprawy poziomu rozwoju gospodarczego. Można zatem przyjąć, że postęp techniczny jest niezmiernie ważny zarówno dla jakości życia, jak i dla utrzymania konkurencyjności gospodarki kraju na rynkach międzynarodowych. Encyklopedia PWN podaje, że postęp techniczny, będący wynikiem wdrożenia plonów prac badawczo-rozwojowych, to proces doskonalenia metod wytwórczych poprzez wprowadzenie do produkcji nowych lub udoskonalonych maszyn, urządzeń, aparatury, narzędzi i nowych technologii ${ }^{11}$. Proces ten związany jest $\mathrm{z}$ bardziej efektywnym wykorzystaniem istniejących zasobów oraz prowadzi do unowocześnienia produkowanych dóbr i towarów/ wyrobów $^{12}$. Postęp techniczny stanowi podstawowe narzędzie prowadzące do wzrostu konkurencyjności przedsiębiorstw, jednocześnie wpływa na poprawę

8 Ibidem, s. 27.

9 Ibidem, s. 48.

10 Parlament Europejski, Polityka innowacyjności, Dokument informacyjny o Unii Europejskiej, s. 4, 2016, http://www.europarl.europa.eu/ftu/pdf/pl/FTU_5.9.7.pdf

11 http://encyklopedia.pwn.pl/haslo/postep-techniczny;3960893.html; stan na 25.03.2016 r.

12 M.G. Woźniak, Wzrost gospodarczy. Podstawy teoretyczne, Wydawnictwo Akademii Ekonomicznej w Krakowie, Kraków 2004. 
i intensyfikację procesów wytwórczych ${ }^{13}$. W konsekwencji wzmacnia potencjał gospodarczy kraju i prowadzi do jego większej innowacyjności.

Postęp techniczny jest wynikiem świadomego działania człowieka, którego celem jest rozwój środków technicznych ${ }^{14}$. Postęp techniczny ukierunkowany jest na osiaganie lepszych efektów zarówno pod względem ilości, jak i jakości. Znaczenie ma również skrócenie czasu wytworzenia przy jednoczesnym obniżeniu kosztów pracy.

Technologia to wiedza teoretyczna wraz z umiejętnościami jej zastosowania $\mathrm{w}$ praktyce oraz korzystanie $\mathrm{z}$ aparatury technicznej i ciagłe doskonalenie procesów ${ }^{15}$. W ogólnym ujęciu technologia to metody i procedury stosowane w procesie produkcji, który prowadzi do wytworzenia produktów, ale również usług materialnych oraz efektów prac w sferze naukowej. W przedsiębiorstwie technologia obejmuje (1) hardware, czyli wyposażenie fizyczne, (2) software, zatem aktywa niematerialne, oraz (3) orgware, czyli struktury i metody organizacji pozwalające na łączenie hardware i software w spójną całość ${ }^{16}$. Procesy technologiczne stanowią główny element procesów pracy. Dlatego też technologia to z jednej strony sposób przeprowadzania procesu wytwórczego lub produkcyjnego, a z drugiej dziedzina, która związana jest z opracowaniem nowych metod przetwarzania surowców lub produkcji wyrobów ${ }^{17}$.

Postęp technologiczny wynika z ewolucji techniki, czyli ciagłych zmian, co może prowadzić do powstania jednego bądź wielu rozwiązań, z których najważniejszym staje się to, które jest najbardziej efektywne i posiada możliwości zastosowania w praktyce. Postęp technologiczny jednak to nie tylko ewolucja techniki. W konsekwencji nie powinno się utożsamiać postępu technologicznego jedynie z rozwojem techniki ${ }^{18}$. Kontynuując, postęp techniczny to pojęcie względne. Ta sama metoda, produkt czy rozwiązanie może, w zależności od czynników/

13 K. Lacny, M. Janczar-Smuga, Postęp techniczny i technologiczny w produkcji słodu, Nauki Inżynierskie i Technologie 2013/4 (11), s. 77.

14 B. Banach, Rozwój i postęp techniczny na tle ogólnych prawidłowości gospodarczych i cywilizacyjnych: wybrane problemy, Księgarnia Akademicka, Kraków 2010. Do środków technicznych zaliczyć można: aparaturę, maszyny, urządzenia, narzędzia, elektroniczne środki techniczne, roboty i budowle.

15 E. Niedzielska (red.), Technologia przetwarzania danych, Państwowe Wydawnictwo Ekonomiczne, Warszawa 1990.

16 W. Janasz (red.), Innowacje w zrównoważonym rozwoju organizacji, Difin, Warszawa 2011.

17 Ibidem, s. 29.

18 S. Kwiatkowski, Społeczeństwo innowacyjne, PWN, Warszawa 1990, s. 50. 
warunków zewnętrznych, dostarczać różnych efektów dla postępu technicznego ${ }^{19}$. Nowoczesne techniki sprawdzające się, na przykład w krajach Europy Zachodniej czy Stanach Zjednoczonych, niekoniecznie będą odpowiednie dla państw słabiej rozwiniętych. Ten mechanizm działa $\mathrm{w}$ dwie strony - rozwiązania przynoszące postęp w krajach rozwijających się niekoniecznie muszą sprawdzać się w praktyce w przypadku państw wysoko rozwiniętych.

Wynalazczość, technika, technologia, nowe rozwiązania stanowią ważny element w ocenie poziomu innowacyjności gospodarek na całym świecie. Encyklopedia $P W N$ podaje, że ,wynalazek to nowe oryginalne rozwiązanie techniczne lub organizacyjne o charakterze użytkowym, którego powstanie ma znamiona aktu twórczego. Wynalazek może być nowym urządzeniem, nowym tworzywem, przewyższającym pod jakimś względem istniejące materiały, albo nową metodą rozwiązywania jakiegoś problemu, zazwyczaj technicznego" ${ }^{20}$. Jednak żywot wynalazku nie jest taki prosty - musi on przejść długą drogę od koncepcji poprzez prototyp wstępny, poprawki, ewentualne dalsze udoskonalenia, aż do wersji ostatecznej, która w końcu znajdzie komercyjne zastosowanie. Dopiero wówczas można przyjąć, że mamy do czynienia z innowacją ${ }^{21}$. Warto podkreślić, że droga od wynalazku do rynkowego zastosowania nie jest wcale prosta. Wiele wynalazków nie znajduje uznania w oczach inwestorów, tym samym mniej lub bardziej oryginalne pomysły nigdy nie trafiają do realizacji.

Większość wynalazków jest ciągle udoskonalana, dzięki czemu zyskuje się rozwiązania najbardziej optymalne na danym etapie rozwoju społeczno-gospodarczego. Ciagły proces zmian i udoskonaleń wymusza konkurencyjny rynek oraz konsument ze zmieniającymi się swoimi potrzebami i oczekiwaniami wobec użyteczności poszczególnych dóbr i usług. Przykładem może być produkcja telewizorów z ekranami kineskopowymi, które zostały wyparte przez lżejsze ekrany LCD. Jewkes (1958) zauważa, iż między nauką i wynalazczością istnieje dodatnie sprzężenie zwrotne. Dobrym przykładem jest przypadek maszyny parowej. Powstała ona na długo przed sformułowaniem praw fizyki, które nią

19 K. Wandelt, Studia nad postępem technicznym i organizacyjnym, Poznańskie Towarzystwo Przyjaciół Nauk, Poznań 1972, s. 28, za: S. Kwiatkowski, Przedsiębiorczość intelektualna, Wydawnictwo Naukowe PWN, Warszawa 2000, s. 53.

20 http://encyklopedia.pwn.pl/haslo/wynalazek;3998913.html; stan na 19.03.2016 r.

21 S. Gomułka, Teoria innowacji $i$ wzrostu gospodarczego, Centrum Analiz Społeczno-Ekonomicznych, Warszawa 1998, s. 17. 
rządziły. Jej istnienie doprowadziło jednak do powstania termodynamiki, dzięki której później powstał silnik Diesla ${ }^{22}$.

Wynalazki często powstają z potrzeby chwili - ich narodziny są wynikiem zgłaszanego zapotrzebowania lub obowiązującego trendu na rynku. Nie zawsze jednak uwarunkowania zewnętrzne sprzyjają wynalazczości, mogą również ten proces hamować. Obawy społeczeństwa, niechęć ludzi przed zmianami mogą opóźniać wprowadzenie wynalazku do obiegu. Należy zadbać o to, aby badania naukowe prowadziły do wzbogacenia dotychczasowej wiedzy w danej dziedzinie, a jednocześnie stanowiły odpowiedź dla bezpośrednich potrzeb społeczeństwa i prowadzily do rozwiązania praktycznych problemów. W związku z tym cele prowadzonych prac naukowych powinny jasno wynikać z zainteresowań badaczy. Należy zapewnić im odpowiedni poziom swobody w realizacji własnych przedsięwzięć naukowych. Polityka państwa powinna skupić się na określeniu/ wytyczeniu preferowanych kierunków prac naukowych, tak aby dotyczyły one rzeczywistych problemów i prowadziły do racjonalnych rozwiązań. Wiedza i nauka służą dobru społecznemu dopiero wówczas, gdy efekty prac badawczych znajdują zastosowanie w praktyce. Brak powiązania pomiędzy nauką a praktyką nie prowadzi do wzrostu gospodarczego kraju, wręcz przeciwnie - skutkuje spadkiem kapitału społecznego. Niezbędne jest kreowanie nowych idei, które mają nie tylko teoretyczne odzwierciedlenie, ale są również utylitarne.

Szczególny nacisk należy położyć na związki pomiędzy wiedzą a innowacjami, które wpływają na wzrost konkurencyjności przedsiębiorstw i gospodarek. W ostatnich dekadach istotnie rośnie znaczenie wiedzy, której praktyczne zastosowanie utożsamiane jest $\mathrm{z}$ innowacjami. Rozwój wiedzy jest ściśle skorelowany z innowacjami - popyt na wiedzę zgłaszany przez rynek jest zaspokajany przez implementacje innowacji, które polegają na wykreowaniu czegoś nowego, co wzbogaca aktualny stan wiedzy. Dodatkowo, innowacje są efektem przemiany istniejącej już wiedzy w nowy proces albo produkt. W związku z tym należy również zauważyć, jak ważną rolę odgrywa mobilność wiedzy w gospodarce. W obecnej dobie jest to umożliwiane przez wiele czynników, m.in. dzięki dostępowi do bogatych źródeł wiedzy i systematycznemu powiększaniu się ich; globalizacji gospodarki ułatwiającej dostęp do światowych rynków; wzrostowi znaczenia efektów innowacji, zwłaszcza produktów high-tech; przyspieszeniu wdrożenia innowacji zarówno do produkcji, jak i na rynek produktów. W związku

22 J. Jewkes, D. Sawers, R. Stillerman, The sources of invention, Macmillan, London 1958, za: S. Gomulka, Teoria innowacji i wzrostu gospodarczego, Centrum Analiz Społeczno-Ekonomicznych, Warszawa 1998, s. 17-18. 
z tym można przyjąć, że siłą napędową działalności innowacyjnej jest mobilność wiedzy ${ }^{23}$.

Ważne miejsce w dyskusji nad rozwojem innowacyjnym kraju zajmują również Narodowe Systemy Innowacji (NSI). Jest to zespół instytucji, które wspierają powstawanie i rozwój nowych technologii oraz sprzyjają ich popularyzacji. Zdolności do generowania innowacji w danym kraju w dużej mierze zależą od uwarunkowań ekonomicznych, geograficznych i historycznych, systemu instytucjonalnego, ale też tradycji kulturowych oraz wartości społecznych. W związku z tym określenie jednego uniwersalnego systemu wydaje się być niemożliwym. Możliwe jednak jest wskazanie pewnych elementów, które zapewniają właściwe funkcjonowanie systemu. Christopher Freeman, który jako pierwszy wprowadził określenie „,narodowych systemów innowacji”, przyjmował, że jest to sieć współdziałających ze sobą instytucji zarówno w sektorze publicznym, jak i prywatnym, których wzajemna współpraca oraz aktywność inicjują import, doskonalenie i rozpowszechnianie nowych technologii ${ }^{24}$. NSI to także zespół powiązanych ze sobą instytucjonalnie i strukturalnie elementów występujących w gospodarce narodowej i społeczeństwie, które zarówno generują, selekcjonują, jak i wchłaniają innowacje techniczne ${ }^{25}$. Organizacje te mogą działać samodzielnie, jak i w powiązaniu z innymi uczestnikami systemu. Za głównych uczestników polskiego systemu innowacji uznaje się:

- sektor rządowy, czyli władze różnego szczebla, głównie ministerstwa, szczególnie te związane z edukacją i gospodarką, organizacje pozarządowe, w tym fundacje, itp.;

- sektor przedsiębiorstw - dużych, MŚP oraz zagranicznych i międzynarodowych z zapleczem badawczym własnym lub zagranicznym;

- sektor edukacji i nauki, w szczególności szkoły wyższe i instytuty badawcze.

\section{Innowacyjność krajów UE w rankingach międzynarodowych}

W latach 2001-2010 Europejska Tablica Innowacyjności (European Innovation Scoreboard-EIS) prezentowała poziom innowacyjności w krajach Unii Europejskiej. Od roku 2011 została ona zastąpiona przez Unijną Tablicę Innowacyjności

${ }^{23}$ Innovation Policy in a Knowledge-Based Economy, OECD, Paris 2002, s. 3-4.

24 Ch. Freeman, Technology and Economic Performance: Lessons From Japan, Printer Publisher, London 1987, s. 1-4.

25 E. Okoń-Horodyńska, Państwo narodowe a proces globalizacji, Wydawnictwo Akademii Ekonomicznej w Katowicach, Katowice 1998, s. 79. 
(Innovation Union Scoreboard - IUS $)^{26}$. Prezentowane w tablicach rankingi innowacyjności mają za zadanie porównać stopień zaawansowania innowacyjnego w państwach Unii za pomocą wybranych zmiennych diagnostycznych odnoszących się do różnych aspektów gospodarczych i społecznych. Na przestrzeni lat metodologia EIS ewoluowała, włączano nowe, kolejne mierniki w miejsce eliminowanych poprzedników. Do opracowania miernika syntetycznego SII wykorzystywane są dane pochodzące z badania pierwotnego Community Innovation Survey $(C I S)$ oraz dane pochodzące z baz Eurostatu. Wskaźniki podzielone są na dwie kategorie i pięć grup tematycznych. Warstwa input składała się ze wskaźników opisujących wkład $\mathrm{w}$ działalność innowacyjną, natomiast w warstwie output prezentowane są efekty ${ }^{27}$. Przejście z edycji EIS-2009 do edycji IUS-2010 skutkowało zmniejszeniem liczby zmiennych z 29 do $25^{28}$. Tabela 1 porównuje różnice występujące między nimi.

Komisja Europejska wdrożyła przedsięwzięcie EIS w ramach realizacji projektu Trend Chart on Innovation Policy in Europe. Projekt ten zastapiony został przez PRO INNO Europe ${ }^{29}$. Ocena innowacyjności w ramach IUS dokonywana jest dla wszystkich krajów członkowskich, ale również Szwajcarii, Islandii, Norwegii, Serbii, Macedonii i Turcji. W raporcie zawarte są również zestawienia pokazujące relację między UE-28 a jej głównymi światowymi konkurentami, czyli Stanami Zjednoczonymi, Japonią, Kanadą, Australią, a także państwami BRICS (Brazylia, Rosja, Indie, Chiny, Korea Południowa).

TABELA 1: Porównanie Rankingów EIS-2009 oraz IUS-2010

\begin{tabular}{|c|c|c|}
\hline$E I S-2009$ & IUS-2010 & Komentarz \\
\hline \multicolumn{3}{|c|}{ Czynniki wspomagające innowacyjność } \\
\hline \multicolumn{3}{|c|}{ Zasoby ludzkie } \\
\hline $\begin{array}{l}\text { Absolwenci szkół wyższych } \\
\text { kierunków ścisłych i technicznych oraz } \\
\text { społecznych i humanistycznych w wieku } \\
\text { 20-29 lat na } 1000 \text { mieszkańców }\end{array}$ & - & $\begin{array}{l}\text { Brak wskaźnika } \\
\text { w IUS-2010 }\end{array}$ \\
\hline
\end{tabular}

26 http://www.pi.gov.pl/parp/chapter_96055.asp?soid=DA555BE3925A41B69D8B97226EA582F7, stan na 5.05.2016 r.

27 G. Niedbalska, Innowacje i transfer technologii. Stownik pojęć, K.B. Matusiak (red.), Polska Agencja Rozwoju Przedsiębiorczości, Warszawa 2011, s. 69.

28 H. Hollanders, S. Tarantola, Innovation Union Scoreboard 2010 - Methodology report, Pro Inno Europe, 2011, s. 2.

http://www.eustat.eus/documentos/datos/PI_metod/IUS_2010_Methodology_report_c.pdf; stan na $28.05 .2016 \mathrm{r}$.

29 G. Niedbalska, Innowacje..., s. 68. 


\begin{tabular}{|c|c|c|}
\hline EIS-2009 & IUS-2010 & Komentarz \\
\hline $\begin{array}{l}\text { Osoby posiadające stopień doktora } \\
\text { nauk ścisłych i technicznych oraz } \\
\text { społecznych i humanistycznych w wieku } \\
\text { 25-34 lat na } 1000 \text { mieszkańców } \\
\end{array}$ & $\begin{array}{l}\text { Liczba nowych osób ze stopniem } \\
\text { doktora w wieku 25-34 lat } \\
\text { na } 1000 \text { mieszkańców }\end{array}$ & $\begin{array}{l}\text { Poszerzenie } \\
\text { wskaźnika }\end{array}$ \\
\hline $\begin{array}{l}\text { Udział osób z wyższym wykształceniem } \\
\text { w grupie wiekowej 25-64 lat } \\
\text { w procentach }\end{array}$ & $\begin{array}{l}\text { Procent osób w grupie } \\
\text { wiekowej 30-34 lat z pełnym } \\
\text { wykształceniem wyższym }\end{array}$ & $\begin{array}{l}\text { Zawężenie grupy } \\
\text { wiekowej }\end{array}$ \\
\hline \begin{tabular}{|l|} 
Procent osób w grupie wiekowej \\
25-64 lat w kształceniu ustawicznym
\end{tabular} & - & $\begin{array}{l}\text { Brak wskaźnika } \\
\text { w IUS-2010 }\end{array}$ \\
\hline $\begin{array}{l}\text { Poziom zdobytego wykształcenia } \\
\text { średniego wśród młodych }\end{array}$ & $\begin{array}{l}\text { Procent osób w grupie wiekowej } \\
\text { 20-24 lat z wykształceniem co } \\
\text { najmniej średnim }\end{array}$ & $\begin{array}{l}\text { Ten sam } \\
\text { wskaźnik inaczej } \\
\text { nazwany }\end{array}$ \\
\hline \multicolumn{3}{|c|}{ Otwarty, wspaniały i atrakcyjny system badań } \\
\hline- & \begin{tabular}{|l} 
Międzynarodowe \\
współautorstwo publikacji \\
naukowych na milion \\
mieszkańców \\
\end{tabular} & Nowy wskaźnik \\
\hline- & $\begin{array}{l}\text { Publikacje naukowe wydanych } \\
\text { w } 10 \% \text { najczęściej cytowanych } \\
\text { publikacjach światowych jako } \\
\text { procent wszystkich publikacji } \\
\text { naukowych kraju }\end{array}$ & Nowy wskaźnik \\
\hline- & $\begin{array}{l}\text { Odsetek doktorantów spoza UE } \\
\text { w ogólnej liczbie doktorantów } \\
\text { kraju }\end{array}$ & Nowy wskaźnik \\
\hline \multicolumn{3}{|c|}{ Finansowanie i wsparcie } \\
\hline $\begin{array}{l}\text { Udział wydatków publicznych na } \mathrm{B}+\mathrm{R} \\
\text { jako procent } \mathrm{PKB}\end{array}$ & $\begin{array}{l}\text { Udział wydatków publicznych na } \\
\text { B+R jako procent } \mathrm{PKB}\end{array}$ & $\begin{array}{l}\text { Wskaźnik } \\
\text { identyczny }\end{array}$ \\
\hline $\begin{array}{l}\text { Udział inwestycji typu venture capital } \\
\text { w przedsięwzięcia jako procent PKB }\end{array}$ & $\begin{array}{l}\text { Udział inwestycji typu venture } \\
\text { capital w przedsięwzięcia jako } \\
\text { procent PKB }\end{array}$ & $\begin{array}{l}\text { Wskaźnik } \\
\text { identyczny }\end{array}$ \\
\hline Kredyty prywatne jako procent PKB & - & $\begin{array}{l}\text { Brak wskaźnika } \\
\text { w IUS-2010 }\end{array}$ \\
\hline $\begin{array}{l}\text { Dostęp przedsiębiorstw do łączy } \\
\text { szerokopasmowych }\end{array}$ & - & $\begin{array}{l}\text { Brak wskaźnika } \\
\text { w IUS-2010 }\end{array}$ \\
\hline \multicolumn{3}{|c|}{ Aktywność firm } \\
\hline \multicolumn{3}{|c|}{ Inwestycje przedsiębiorstw } \\
\hline $\begin{array}{l}\text { Udział wydatków przedsiębiorstw } \\
\text { na B+R w PKB }\end{array}$ & $\begin{array}{l}\text { Udział wydatków } \\
\text { przedsiębiorstw na B+R w PKB }\end{array}$ & $\begin{array}{l}\text { Wskaźnik } \\
\text { identyczny }\end{array}$ \\
\hline $\begin{array}{l}\text { Udział wydatków na technologie IT } \\
\text { w PKB }\end{array}$ & - & $\begin{array}{l}\text { Brak wskaźnika } \\
\text { w IUS-2010 }\end{array}$ \\
\hline
\end{tabular}




\begin{tabular}{|c|c|c|}
\hline EIS-2009 & IUS-2010 & Komentarz \\
\hline $\begin{array}{l}\text { Procent obrotów wydatków na } \\
\text { innowacje niezwiązane z B+R }\end{array}$ & $\begin{array}{l}\text { Procent obrotów wydatków na } \\
\text { innowacje niezwiązane z B+R }\end{array}$ & $\begin{array}{l}\text { Wskaźnik } \\
\text { identyczny }\end{array}$ \\
\hline \multicolumn{3}{|c|}{ Powiązania i przedsiębiorczość } \\
\hline $\begin{array}{l}\text { Odsetek MŚP wprowadzających własne } \\
\text { innowacje w ogólnej liczbie MŚP }\end{array}$ & $\begin{array}{l}\text { Odsetek MŚP wprowadzających } \\
\text { własne innowacje w ogólnej } \\
\text { liczbie MŚP }\end{array}$ & $\begin{array}{l}\text { Wskaźnik } \\
\text { identyczny }\end{array}$ \\
\hline $\begin{array}{l}\text { Odsetek kooperujących MŚP w zakresie } \\
\text { innowacji w ogólnej liczbie MŚP }\end{array}$ & $\begin{array}{l}\text { Odsetek kooperujących MŚP } \\
\text { w zakresie innowacji w ogólnej } \\
\text { liczbie MŚP }\end{array}$ & $\begin{array}{l}\text { Wskaźnik } \\
\text { identyczny }\end{array}$ \\
\hline $\begin{array}{l}\text { Wskaźnik odnawialności firm - liczba } \\
\text { zakładanych i zamykanych MŚP } \\
\text { w ogólnej liczbie MŚP }\end{array}$ & - & $\begin{array}{l}\text { Brak wskaźnika } \\
\text { w IUS-2010 }\end{array}$ \\
\hline $\begin{array}{l}\text { Publiczno-prywatne ko-publikacje na } \\
\text { milion mieszkańców }\end{array}$ & $\begin{array}{l}\text { Publiczno-prywatne ko- } \\
\text { publikacje na milion } \\
\text { mieszkańców }\end{array}$ & $\begin{array}{l}\text { Wskaźnik } \\
\text { identyczny }\end{array}$ \\
\hline Przepustowość & Kapitał intelektualny & $\begin{array}{l}\text { Zmiana nazwy } \\
\text { podgrupy }\end{array}$ \\
\hline $\begin{array}{l}\text { Liczba wynalazków zgłoszonych do } \\
\text { EPO na milion mieszkańców }\end{array}$ & - & $\begin{array}{l}\text { Brak wskaźnika } \\
\text { w IUS-2010 }\end{array}$ \\
\hline- & \begin{tabular}{|l} 
Patenty zgłoszone do PCT \\
w bilionach PKB (w PPP euro)
\end{tabular} & Nowy wskaźnik \\
\hline- & $\begin{array}{l}\text { Patenty zgłoszone do PCT } \\
\text { w bilionach PKB (w PPP euro) } \\
\text { zaangażowane społecznie } \\
\text { (zmniejszenie zmian } \\
\text { klimatycznych; zdrowotne) }\end{array}$ & Nowy wskaźnik \\
\hline $\begin{array}{l}\text { Liczba społecznościowych znaków } \\
\text { towarowych na milion mieszkańców }\end{array}$ & $\begin{array}{l}\text { Liczba społecznościowych } \\
\text { znaków towarowych na bilion } \\
\text { PKB }\end{array}$ & $\begin{array}{l}\text { Zmiana } \\
\text { denominatora }\end{array}$ \\
\hline $\begin{array}{l}\text { Liczba społecznościowych wzorów } \\
\text { przemysłowych na milion mieszkańców }\end{array}$ & $\begin{array}{l}\text { Liczba społecznościowych } \\
\text { wzorów przemysłowych na } \\
\text { bilion PKB }\end{array}$ & $\begin{array}{l}\text { Zmiana } \\
\text { denominatora }\end{array}$ \\
\hline $\begin{array}{l}\text { Bilans płatniczy w zakresie technologii } \\
\text { jako \% PKB }\end{array}$ & - & $\begin{array}{l}\text { Zmiana kategorii } \\
\text { wskaźnika }\end{array}$ \\
\hline \multicolumn{3}{|c|}{ Efekty } \\
\hline \multicolumn{3}{|c|}{ Innowatorzy } \\
\hline $\begin{array}{l}\text { Odsetek MŚP wprowadzających } \\
\text { produktowe lub usługowe innowacje }\end{array}$ & $\begin{array}{l}\text { Odsetek MŚP wprowadzających } \\
\text { produktowe lub usługowe } \\
\text { innowacje }\end{array}$ & $\begin{array}{l}\text { Wskaźnik } \\
\text { identyczny }\end{array}$ \\
\hline $\begin{array}{l}\text { Odsetek MŚP wprowadzających } \\
\text { marketingowe lub organizacyjne } \\
\text { innowacje }\end{array}$ & $\begin{array}{l}\text { Odsetek MŚP wprowadzających } \\
\text { marketingowe lub organizacyjne } \\
\text { innowacje }\end{array}$ & $\begin{array}{l}\text { Wskaźnik } \\
\text { identyczny }\end{array}$ \\
\hline
\end{tabular}




\begin{tabular}{|c|c|c|}
\hline EIS-2009 & IUS-2010 & Komentarz \\
\hline $\begin{array}{l}\text { Procent innowatorów ulepszających } \\
\text { efektywność wykorzystania zasobów } \\
\text { w ogólnej liczbie firm }\end{array}$ & - & $\begin{array}{l}\text { Brak wskaźnika } \\
\text { w IUS-2010 }\end{array}$ \\
\hline- & $\begin{array}{l}\text { Innowacyjne przedsiębiorstwa } \\
\text { szybkiego wzrostu }\end{array}$ & Nowy wskaźnik \\
\hline \multicolumn{3}{|c|}{ Gospodarcze efekty innowacji } \\
\hline $\begin{array}{l}\text { Udział zatrudnionych w sektorach } \\
\text { produkcji średniowysokiej i wysokiej } \\
\text { techniki }\end{array}$ & - & $\begin{array}{l}\text { Brak wskaźnika } \\
\text { w IUS-2010 }\end{array}$ \\
\hline $\begin{array}{l}\text { Udział zatrudnionych } \\
\text { w wiedzochłonnych usługach }\end{array}$ & - & $\begin{array}{l}\text { Brak wskaźnika } \\
\text { w IUS-2010 }\end{array}$ \\
\hline- & $\begin{array}{l}\text { Udział zatrudnionych } \\
\text { w wiedzochłonnych sektorach } \\
\text { (przemysł i usługi) }\end{array}$ & Nowy wskaźnik \\
\hline $\begin{array}{l}\text { Procent eksportu produktów } \\
\text { średniowysokiej i wysokiej techniki } \\
\text { w eksporcie ogółem }\end{array}$ & $\begin{array}{l}\text { Procent eksportu produktów } \\
\text { średniowysokiej i wysokiej } \\
\text { techniki w eksporcie ogółem }\end{array}$ & $\begin{array}{l}\text { Wskaźnik } \\
\text { identyczny }\end{array}$ \\
\hline $\begin{array}{l}\text { Procent eksportu wiedzochłonnych } \\
\text { usług w eksporcie ogółem }\end{array}$ & $\begin{array}{l}\text { Procent eksportu } \\
\text { wiedzochłonnych usług } \\
\text { w eksporcie ogółem }\end{array}$ & $\begin{array}{l}\text { Wskaźnik } \\
\text { identyczny }\end{array}$ \\
\hline $\begin{array}{l}\text { Procent udziałów sprzedaży nowych } \\
\text { lub zmodernizowanych produktów dla } \\
\text { rynku w sprzedaży przedsiębiorstw } \\
\text { ogółem }\end{array}$ & \multirow{2}{*}{$\begin{array}{l}\text { Procent udziałów sprzedaży } \\
\text { nowych lub zmodernizowanych } \\
\text { produktów dla rynku i nowych } \\
\text { lub zmodernizowanych } \\
\text { produktów dla rynku } \\
\text { przedsiębiorstw w sprzedaży } \\
\text { przedsiębiorstw ogółem }\end{array}$} & \multirow{2}{*}{$\begin{array}{l}\text { Połączenie } \\
\text { wskaźników }\end{array}$} \\
\hline $\begin{array}{l}\text { Procent udziałów sprzedaży nowych } \\
\text { lub zmodernizowanych produktów dla } \\
\text { rynku przedsiębiorstw w sprzedaży } \\
\text { przedsiębiorstw ogółem }\end{array}$ & & \\
\hline- & $\begin{array}{l}\text { Przychody z patentów i licencji } \\
\text { z zagranicy jako procent PKB }\end{array}$ & Nowy wskaźnik \\
\hline
\end{tabular}

Ź r ó d ł o: H. Hollanders, S. Tarantola, Innovation Union Scoreboard 2010-Methodology report, Pro Inno Europe, 2011, s. 4-6, tłum. własne.

Wykres 1 przedstawia porównanie wartości wskaźnika Summary Innovation Index (SII) dla poszczególnych krajów członkowskich w roku 2014 i 2010. Niezmiennie czołówka rankingu należy do krajów skandynawskich oraz Niemiec. Znajdują się w niej kraje określane jako liderzy innowacji (ang. innovation leaders), osiagają one wyniki o co najmniej $20 \%$ wyższe niż średni wynik dla EU-28. Kolejną grupę stanowią państwa doganiające liderów (ang. innovation followers), znajduje się tutaj Holandia, Luksemburg, Wielka Brytania, Irlandia, Belgia, Francja, Austria, Słowenia. Wyniki tych krajów w zakresie innowacyjności 
przekraczają średnią dla EU-28 o mniej niż 20\% i jednocześnie mogą być niższe od tej średniej o co najwyżej 10\%. Grupa trzecia to umiarkowani innowatorzy (ang. moderate innovators): Estonia, Czechy, Cypr, Włochy, Portugalia, Malta, Hiszpania, Węgry, Grecja, Słowacja, Chorwacja, Polska, Litwa. Są to kraje, dla których wartości wskaźnika SII są niższe od średniej EU-28 o więcej niż 10\%, ale jednocześnie stanowią nie mniej niż 50\% tej średniej. Ostatnia grupa państw, najsłabszych pod względem poziomu innowacyjności, to kraje „doganiające”, tak zwani skromni innowatorzy (ang. catching-up countries). Wyniki tych krajów w zakresie innowacyjności plasują się poniżej 50\% średniego wyniku dla UE-2 $8^{30}$. Reprezentanci: Łotwa, Bułgaria, Rumunia.

WYKRES 1: Summary Innovation Index - porównanie wyników państw członkowskich UE-2014 vs. 2010

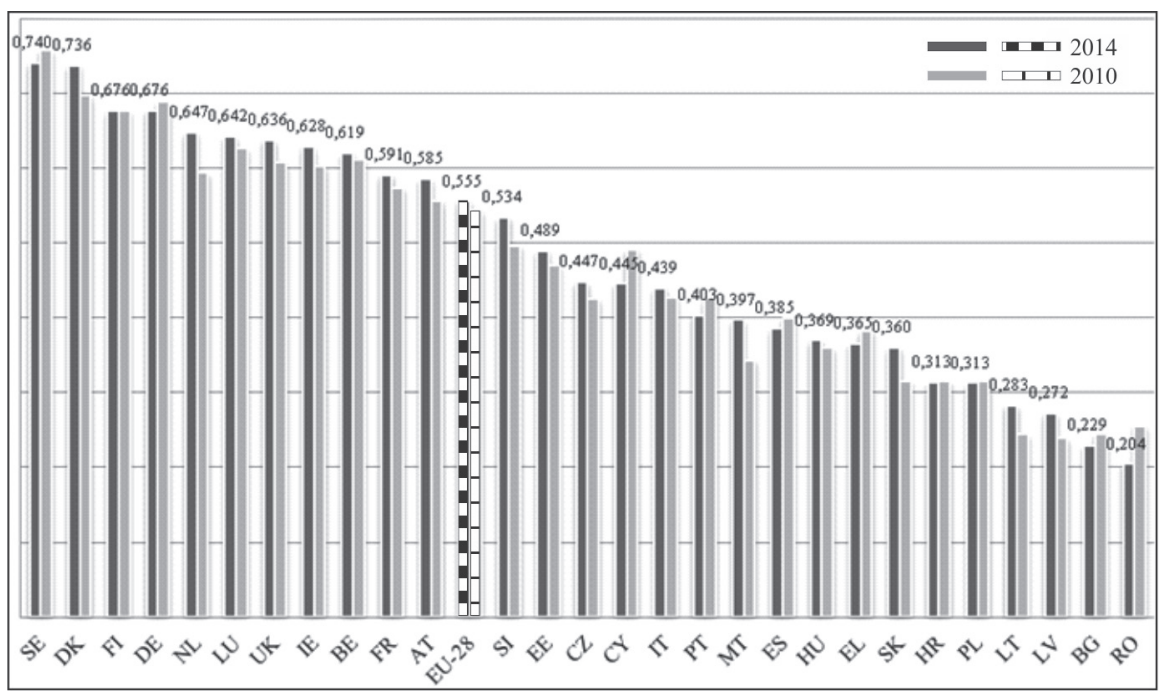

Ź r ó d ł o: opracowanie własne na podstawie Summary Innovation Index 2014, Summary Innovation Index 2010, por. European Commission, Innovation Union Scoreboard 2015, Internal Market Industry, Entrepreneurship and SMEs, Belgium 2015, http://ec.europa.eu/growth/industry/innovation/facts-figures/scoreboards/index_en.htm

W porównaniu z wynikami zeszłorocznego zestawienia Polska zamieniła się miejscami z Litwą i tym samym poprawiła swoje miejsce w rankingu, awansując z pozycji 25 na 24 . Zrównała się tym samym z wartością wskaźnika Chorwacji.

30 M. Dąbrowa, Czy gospodarka w Polsce jest innowacyjna?, Zeszyty Naukowe Małopolskiej Wyższej Szkoły Ekonomicznej w Tarnowie 2014/24/1, s. 74. 
Warto zwrócić również uwagę na różnice występujące pomiędzy rozwiniętą Północą i Zachodem kontynentu a gospodarkami Południa i Wschodu (głównie byłe kraje komunistyczne).

Wynikiem współpracy ekspertów z Cornell University, jednej z dobrze znanych na świecie szkół zarządzania i biznesu INSEAD - the Business School of the World, oraz Światowej Organizacji Zasobów Intelektualnych (ang. The World Intellectual Property Organization - WIPO) jest publikowany od roku 2007 Globalny Indeks Innowacyjności (Global Innovation Index - GII). Raport publikowany jest cyklicznie, raz do roku. W ósmej edycji raportu przedstawionych zostało 141 gospodarek, tym samym badanie obejmuje 95,1\% ludności żyjącej na świecie oraz 98,6\% światowego PKB (US\$) 31. Ogólnoświatowy charakter rankingu umożliwia porównanie rozwoju poszczególnych gospodarek, ale i kontynentów. W skład Globalnego Indeksu Innowacyjności wchodzi 79 wskaźników indywidualnych, które są podzielone na trzy kategorie ${ }^{32}$ :

- obiektywne/ilościowe/twarde dane (55),

- wskaźniki złożone/indeksy agregatowe (19),

- subiektywne/jakościowe/miękkie dane (5).

Wskaźniki z pierwszej kategorii są zazwyczaj sprzężone z głównymi charakterystykami gospodarki, jak na przykład z wartością $\mathrm{PKB}$, powierzchnią czy liczbą ludności. Wszystkie z mierników zostają znormalizowane tzw. metodą min-max, gdzie ich wartości należą do przedziału $[0,100]$. Uprzednio wskaźniki indywidualne przekształcone zostają do postaci stymulant, w związku z tym wyższe ich wartości przekładają się na większą innowacyjność gospodarki. Każda ze zmiennych zostaje przyporządkowana do odpowiedniej grupy, a następnie filaru innowacyjności, które łącznie składają się na dwa subindeksy - subindeks nakładów innowacyjnych (Innovation Input Sub-Index) oraz subindeks efektów działalności innowacyjnej (Innovation Output Sub-Index). Fundamentalnymi elementami budowy Global Innovation Index jest siedem grup, w ramach których wyróżnione są dodatkowo po trzy obszary zmiennych. Wyniki poszczególnych grup oraz filarów to średnia ważona z wartości wybranych wskaźników indywidualnych.

31 The Global Innovation Index 2015. Effective Innovation Policies for Development, Fontainebleau, Ithaca, and Geneva, 2015, s. 9, https://www.globalinnovationindex.org/userfiles/file/reportpdf/ gii-full-report-2015-v6.pdf; https://www.globalinnovationindex.org/content/page/framework/; stan na 17.05.2016 r.

32 Raport Global Innovation Index 2015, s. 441, tłumaczenie własne https://www.globalinnovationindex.org/userfiles/file/reportpdf/GII-2015-v5.pdf; stan na 17.05.2016 r. 
TABELA 2: Budowa wskaźnika Global Innovation Index - edycja 2015

\begin{tabular}{|c|c|c|}
\hline \multirow{15}{*}{$\begin{array}{l}\text { Wskaźnik nakładów } \\
\text { innowacyjnych }\end{array}$} & \multirow{3}{*}{ Instytucje } & Otoczenie polityczne \\
\hline & & Otoczenie prawne \\
\hline & & Otoczenie biznesowe \\
\hline & \multirow{3}{*}{$\begin{array}{l}\text { Zasoby ludzkie } \\
\text { i badania }\end{array}$} & Edukacja \\
\hline & & Szkolnictwo wyższe \\
\hline & & Badania i rozwój \\
\hline & \multirow{3}{*}{ Infrastruktura } & ICT \\
\hline & & Infrastruktura ogólna \\
\hline & & Zrównoważenie rozwoju ekologicznego \\
\hline & \multirow{3}{*}{$\begin{array}{l}\text { Doświadczenie } \\
\text { rynkowe }\end{array}$} & Kredyty \\
\hline & & Inwestycje \\
\hline & & Handel i konkurencja \\
\hline & \multirow{3}{*}{$\begin{array}{l}\text { Doświadczenie } \\
\text { przedsiębiorstw }\end{array}$} & Wiedza pracowników \\
\hline & & Innowacyjna współpraca \\
\hline & & Absorpcja wiedzy \\
\hline \multirow{6}{*}{$\begin{array}{l}\text { Wskaźnik efektów } \\
\text { innowacji }\end{array}$} & \multirow{3}{*}{$\begin{array}{l}\text { Efekty w wiedzy } \\
\text { i technologii }\end{array}$} & Tworzenie wiedzy \\
\hline & & Wpływ wiedzy \\
\hline & & Dyfuzja wiedzy \\
\hline & \multirow{3}{*}{$\begin{array}{l}\text { Efekty } \\
\text { w kreatywności }\end{array}$} & Wartości niematerialne i prawne \\
\hline & & Dobra i usługi kreatywne \\
\hline & & Kreatywność internetowa \\
\hline
\end{tabular}

Źr ó d ł o: https://www.globalinnovationindex.org/userfiles/file/reportpdf/GII-2015-v5.pdf; stan na 17.05.2016 r. Raport Global Innovation Index 2015, s. 76, tłum. własne.

Najlepiej rozwinięte gospodarki na świecie pod względem innowacyjności (najbardziej innowacyjne gospodarki) według oceny rankingu GII, wraz z wartościami wskaźnika, przedstawia tabela 3. Trzeba zauważyć, że czołówka rankingu należy do kontynentu europejskiego, w tym do państw członkowskich UE (7 reprezentantów). Niekwestionowanym liderem jest Szwajcaria pozostająca jednak poza strukturami unijnymi. Wśród najbardziej innowacyjnych gospodarek pojawia się również USA oraz Singapur.

TABELA 3: Czołówka rankingu GII - edycja 2015

\begin{tabular}{|c|l|c|}
\hline Miejsce & \multicolumn{1}{|c|}{ Kraj } & Wynik GII (0-100) \\
\hline 1 & Szwajcaria & 68,30 \\
\hline 2 & Wielka Brytania & 62,42 \\
\hline 3 & Szwecja & 62,40 \\
\hline
\end{tabular}




\begin{tabular}{|c|l|c|}
\hline Miejsce & \multicolumn{1}{|c|}{ Kraj } & Wynik GII (0-100) \\
\hline 4 & Holandia & 61,58 \\
\hline 5 & USA & 59,10 \\
\hline 6 & Finlandia & 59,36 \\
\hline 7 & Singapur & 59,13 \\
\hline 8 & Irlandia & 59,02 \\
\hline 9 & Luksemburg & 57,70 \\
\hline 10 & Dania & \\
\hline
\end{tabular}

Źr ó dło: https://www.globalinnovationindex.org/userfiles/file/reportpdf/GII-2015-v5.pdf; stan na 17.05.2016 r. Raport Global Innovation Index 2015, s. 50, tłum. własne.

Już poza ścisłą czołówką, jednak nadal w rankingu GII, kraje UE zajmują stosunkowo wysokie miejsca, a wartości indeksu dla poszczególnych gospodarek stanowią co najmniej $62 \%$ najwyższej wartości indeksu. W pierwszej połowie zestawienia znajdują się gospodarki ${ }^{33}$ : Niemiec (12 miejsce), Austrii (18), Francji (21), Estonii (23), Czech (24), Belgii (25), Hiszpanii (27), Słowenii (28), Portugalii (30), Włoch (31), Łotwy (33), Węgier (35), Słowacji (36), Litwy (38), Bułgarii (39), Chorwacji (40), Grecji (45), Polski (46). Pozycja Polski na tle pozostałych krajów członkowskich jest jednak mało zadowalająca. Spośród państw UE gorszą pozycję w rankingu GII zajmuje jedynie Rumunia (miejsce 54). Zestawienie wyników prezentowanych w rankingach GII oraz SII przedstawia tabela poniżej.

TABELA 4: Zestawienie porównujace wyniki gospodarek unijnych wedtug SII oraz GII*

\begin{tabular}{|l|c|c|c|c|c|l|c|c|c|c|c|}
\hline \multicolumn{1}{|c|}{ Kraj } & GII & GII & SII & SII & $\begin{array}{c}\text { Suma } \\
\text { pozycji }\end{array}$ & Kraj & GII & GII & SII & SII & $\begin{array}{c}\text { Suma } \\
\text { pozycji }\end{array}$ \\
\hline Austria & 9 & 54,07 & 11 & 0,585 & 20 & Litwa & 23 & 42,26 & 25 & 0,283 & 48 \\
\hline Belgia & 13 & 50,91 & 9 & 0,619 & 22 & Luksemburg & 6 & 59,02 & 6 & 0,642 & 12 \\
\hline Bułgaria & 24 & 42,16 & 27 & 0,229 & 51 & Łotwa & 19 & 45,51 & 26 & 0,272 & 45 \\
\hline Chorwacja & 25 & 41,70 & 23 & 0,313 & 48 & Malta & 14 & 50,48 & 18 & 0,397 & 32 \\
\hline Cypr & 20 & 43,51 & 15 & 0,445 & 35 & Niemcy & 8 & 57,05 & 4 & 0,676 & 12 \\
\hline Czechy & 12 & 51,32 & 14 & 0,447 & 26 & Polska & 27 & 40,16 & 24 & 0,313 & 51 \\
\hline Dania & 7 & 57,70 & 2 & 0,736 & 9 & Portugalia & 17 & 46,61 & 17 & 0,403 & 34 \\
\hline Estonia & 11 & 52,81 & 13 & 0,489 & 24 & Rumunia & 28 & 38,20 & 28 & 0,204 & 56 \\
\hline Finlandia & 4 & 59,97 & 3 & 0,676 & 7 & Słowacja & 22 & 42,99 & 22 & 0,360 & 44 \\
\hline Francja & 10 & 53,59 & 10 & 0,591 & 20 & Słowenia & 16 & 48,49 & 12 & 0,534 & 28 \\
\hline
\end{tabular}

33 https://www.globalinnovationindex.org/content/page/data-analysis/; stan na 18.05.2016 r. 


\begin{tabular}{|l|c|c|c|c|c||l|c|c|c|c|c|}
\hline \multicolumn{1}{|c|}{ Kraj } & GII & GII & SII & SII & $\begin{array}{c}\text { Suma } \\
\text { pozycji }\end{array}$ & Kraj & GII & GII & SII & SII & $\begin{array}{c}\text { Suma } \\
\text { pozycji }\end{array}$ \\
\hline Grecja & 26 & 40,28 & 21 & 0,365 & 47 & Szwecja & 2 & 62,40 & 1 & 0,740 & 3 \\
\hline Hiszpania & 15 & 49,07 & 19 & 0,385 & 34 & Węgry & 21 & 43,00 & 20 & 0,369 & 41 \\
\hline Holandia & 3 & 61,58 & 5 & 0,647 & 8 & $\begin{array}{l}\text { Wielka } \\
\text { Brytania }\end{array}$ & 1 & 62,42 & 7 & 0,636 & 8 \\
\hline Irlandia & 5 & 59,13 & 8 & 0,628 & 13 & Włochy & 18 & 46,40 & 16 & 0,439 & 34 \\
\hline
\end{tabular}

* Na podstawie danych wyjściowych - wartości GII - przygotowane zostało niezależne zestawienie uwzględniające jedynie kraje członkowskie UE. Faktyczne pozycje w rankingu GII dla poszczególnych krajów struktur unijnych są inne aniżeli te wskazane w tabeli powyżej.

Ź r ó d ł o: opracowanie własne na podstawie Global Innovation Index - edycja 2015 oraz Summary Innovation Index - edycja 2015.

Rolą międzynarodowych rankingów innowacyjności jest między innymi ukazanie pozycji poszczególnych gospodarek z punktu widzenia wielowymiarowej oceny zjawiska, jakim jest innowacyjność. Bardziej dogłębna analiza poszczególnych elementów składowych mierników syntetycznych pozwala na wyodrębnienie mocnych i słabych stron poszczególnych gospodarek. Przyczynia się tym samym do kreowania właściwej polityki kraju wspierającej rozwój innowacyjny. Nie ulega wątpliwości, że przyjęta metodologia, w tym dobór cech diagnostycznych, ma szczególne znaczenie dla wyników końcowych. Stąd widoczne są znaczne różnice w pozycjach, jakie zajmują poszczególne kraje w rankingu GII oraz SII. Warto podsumować, że tę samą pozycję w rankingu ogólnoświatowym i europejskim zajmuje jedynie 5 krajów (Francja, Luksemburg, Portugalia, Rumunia oraz Słowacja). Dwunastka spośród państw członkowskich jest uplasowana wyżej w rankingu SII aniżeli w rankingu GII. Największe rozbieżności obserwowane są jednak w przypadku krajów, które lepszą pozycję zajmują w ocenie dokonanej przez ranking ogólnoświatowy. Przykładem są tutaj Łotwa i Wielka Brytania, w rankingu SII znalazły się odpowiednio o siedem i sześć pozycji niżej aniżeli w GII.

TABELA 5: Ocena zależności wyników gospodarek unijnych według SII oraz GII

\begin{tabular}{|c|c|c|}
\hline Współczynnik korelacji rang Spearmana & SII & GII \\
\hline SII & 1,000 & 0,918 \\
\hline GII & 0,918 & 1,000 \\
\hline Współczynnik Tau Kendalla & SII & GII \\
\hline SII & 1,000 & 0,746 \\
\hline GII & 0,746 & 1,000 \\
\hline
\end{tabular}




\begin{tabular}{|c|c|c|}
\hline Współczynnik korelacji liniowej Pearsona & SII & GII \\
\hline SII & 1,000 & 0,919 \\
\hline GII & 0,919 & 1,000 \\
\hline
\end{tabular}

Źr ó d ł o: obliczenia własne na podstawie danych pochodzących z Global Innovation Index oraz Summary Innovation Index.

Niemniej jednak ocena zależności pomiędzy wynikami SII i GII dokonana współczynnikiem rang Spearmana, współczynnikiem Kendalla oraz współczynnikiem korelacji liniowej Pearsona wykazała, że występuje duża zbieżność pomiędzy rozpatrywanymi rankingami. Wyniki analizy korelacji miarą Spearmana pomiędzy rankingami krajów UE są bardzo podobne do wyników uzyskanych miarą korelacji Pearsona, co oznacza, że przejście na skalę porządkową nie generuje dużych strat informacji. Warto jeszcze podkreślić, że uzyskane wyniki są istotne statystycznie dla $\mathrm{p}<0,05$.

Kontynuując zapoczątkowany w części teoretycznej wątek dotyczący NSI, warto zauważyć, że do oceny jakości poszczególnych NSI potrzebne jest wyodrębnienie jego głównych determinant, a są to nakłady na działalność $\mathrm{B}+\mathrm{R}$ oraz udział osób pracujących w sektorze $\mathrm{B}+\mathrm{R}$. Znaczenie ma również struktura nakładów, czyli stosunek nakładów rządowych wobec nakładów prywatnych na sferę $\mathrm{B}+\mathrm{R}$. Warto podkreślić, że liderzy innowacji, chociażby Szwedzi czy Niemcy, bazują na działaniach badawczo-rozwojowych, które w znacznym stopniu są finansowane przez sektor przedsiębiorstw. W Polsce cały czas przeważają nakłady sektora publicznego w działania $B+R$. Podobnie sytuacja wygląda w kwestii odnoszącej się do struktury zatrudnienia. Kadra B+R powinna w głównej mierze być zaangażowana w działalność sektora prywatnego, a nie na odwrót. Z punktu widzenia zasobów ludzkich nie bez znaczenia są również ruchy migracyjne. W krajach o niższym potencjale innowacyjnym często następuje odpływ młodej, aktywnej i dobrze wykształconej ludności, co oddziałuje również na zatrudnienie w sektorze B+R danego kraju. Pogłębia to osłabienie gospodarcze i hamuje postęp technologiczny kraju, ograniczając tym samym rozwój poprzez innowacje.

TABELA 6: Nakłady na działalność badawczo-rozwojowa w UE

\begin{tabular}{|l|c|c|c|c|c|c|}
\hline \multirow{2}{*}{ Obszar } & \multicolumn{2}{|c|}{ Sektor rządowy } & \multicolumn{2}{c|}{ Sektor przedsiębiorstw } & \multicolumn{2}{c|}{ Stosunek nakładów } \\
\cline { 2 - 7 } & 2011 & 2015 & 2011 & 2015 & $\mathrm{p}_{2011} / \mathrm{r}_{2011}$ & $\mathrm{p}_{2015} / \mathrm{r}_{2015}$ \\
\hline UE-28 & 0,25 & 0,24 & 1,24 & 1,3 & $496,0 \%$ & $541,7 \%$ \\
\hline Austria & 0,14 & 0,14 & 1,84 & 2,18 & $1314,3 \%$ & $1557,1 \%$ \\
\hline Belgia & 0,17 & 0,19 & 1,48 & 1,77 & $870,6 \%$ & $931,6 \%$ \\
\hline
\end{tabular}




\begin{tabular}{|l|c|c|c|c|c|c|}
\hline \multirow{2}{*}{ Obszar } & \multicolumn{2}{|c|}{ Sektor rządowy } & \multicolumn{2}{c|}{ Sektor przedsiębiorstw } & \multicolumn{2}{c|}{ Stosunek nakładów } \\
\cline { 2 - 7 } & 2011 & 2015 & 2011 & 2015 & $\mathrm{p}_{2011} / \mathrm{r}_{2011}$ & $\mathrm{p}_{2015} / \mathrm{r}_{2015}$ \\
\hline Bułgaria & 0,19 & 0,2 & 0,28 & 0,7 & $147,4 \%$ & $350,0 \%$ \\
\hline Chorwacja & 0,21 & 0,21 & 0,34 & 0,44 & $161,9 \%$ & $209,5 \%$ \\
\hline Cypr & 0,07 & 0,06 & 0,06 & 0,08 & $85,7 \%$ & $133,3 \%$ \\
\hline Czechy & 0,31 & 0,4 & 0,86 & 1,06 & $277,4 \%$ & $265,0 \%$ \\
\hline Dania & 0,06 & 0,07 & 1,98 & 1,87 & $3300,0 \%$ & $2671,4 \%$ \\
\hline Estonia & 0,19 & 0,16 & 1,46 & 0,69 & $768,4 \%$ & $431,3 \%$ \\
\hline Finlandia & 0,32 & 0,24 & 2,56 & 1,94 & $800,0 \%$ & $808,3 \%$ \\
\hline Francja & 0,3 & 0,29 & 1,4 & 1,45 & $466,7 \%$ & $500,0 \%$ \\
\hline Grecja & 0,16 & 0,26 & 0,23 & 0,32 & $143,8 \%$ & $123,1 \%$ \\
\hline Hiszpania & 0,26 & 0,23 & 0,69 & 0,64 & $265,4 \%$ & $278,3 \%$ \\
\hline Holandia & 0,21 & 0,25 & 1,08 & 1,12 & $514,3 \%$ & $448,0 \%$ \\
\hline Irlandia* & 0,08 & 0,05 & 1,07 & 1,09 & $1337,5 \%$ & $2180,0 \%$ \\
\hline Litwa & 0,18 & 0,18 & 0,24 & 0,28 & $133,3 \%$ & $155,6 \%$ \\
\hline Luksemburg & 0,34 & 0,41 & 0,97 & 0,67 & $285,3 \%$ & $163,4 \%$ \\
\hline Lotwa & 0,16 & 0,16 & 0,19 & 0,15 & $118,8 \%$ & $93,8 \%$ \\
\hline Malta & 0,03 & 0,13 & 0,44 & 0,37 & $1466,7 \%$ & $284,6 \%$ \\
\hline Niemcy & 0,41 & 0,43 & 1,89 & 1,95 & $461,0 \%$ & $453,5 \%$ \\
\hline Polska & 0,26 & 0,25 & 0,22 & 0,47 & $84,6 \%$ & $188,0 \%$ \\
\hline Portugalia & 0,11 & 0,08 & 0,69 & 0,6 & $627,3 \%$ & $750,0 \%$ \\
\hline Rumunia & 0,2 & 0,19 & 0,18 & 0,21 & $90,0 \%$ & $110,5 \%$ \\
\hline Słowacja & 0,18 & 0,33 & 0,25 & 0,33 & $138,9 \%$ & $100,0 \%$ \\
\hline Słowenia & 0,35 & 0,3 & 1,79 & 1,69 & $511,4 \%$ & $563,3 \%$ \\
\hline Szwecja & 0,14 & 0,11 & 2,24 & 2,27 & $1600,0 \%$ & $2063,6 \%$ \\
\hline Węgry & 0,19 & 0,18 & 0,75 & 1,01 & $394,7 \%$ & $561,1 \%$ \\
\hline Wielka Brytania & 0,14 & 0,12 & 1,07 & 1,12 & $764,3 \%$ & $933,3 \%$ \\
\hline Włochy & 0,16 & 0,18 & 0,66 & 0,74 & $412,5 \%$ & $411,1 \%$ \\
\hline
\end{tabular}

* Brak danych dla Irlandii zastapiono wartością z roku 2014.

Ź r ó dło: opracowanie własne na podstawie Eurostat, Research and development expenditure, by sectors of performance, \% of GDP, Business sector and government sector, stan na 2.12.2016 r.

Podsumowując strukturę nakładów na działalność $\mathrm{B}+\mathrm{R}$, warto zauważyć obserwowane pozytywne zmiany, zachodzące w poszczególnych krajach. Jeszcze w roku 2011 na Cyprze, w Polsce i Rumunii nakłady na B+R sektora rządowego 
wyrażone udziałem w PKB były większe aniżeli analogiczne nakłady sektora przedsiębiorstw. W roku 2015 jedynie na Łotwie zanotowano większą intensywność nakładów sektora rządowego wobec sektora przedsiębiorstw. Niezależnie jednak od zanotowanej poprawy w poszczególnych krajach nadal występują znaczące różnice pomiędzy poszczególnymi krajami członkowskimi UE. Struktura nakładów na działalność $\mathrm{B}+\mathrm{R}$ jest cały czas jednym $\mathrm{z}$ tych czynników, który znacząco różnicuje państwa członkowskie z punktu widzenia sumarycznej oceny poziomu ich innowacyjności (współczynnik zmienności w przypadku danych dla sektora przedsiębiorstw jest bliski 70\%). Dodatkowo analizie zostały poddane nakłady finansowe na $\mathrm{B}+\mathrm{R}$ sektora przedsiębiorstw i sektora rządowego w stosunku do nakładów na $\mathrm{B}+\mathrm{R}$ ogółem ${ }^{34}$. Tutaj niestety sytuacja wygląda znacznie mniej optymistycznie. Nadal dość liczną grupę stanowią kraje, w których dominująca część nakładów na $\mathrm{B}+\mathrm{R}$ pochodzi z sektora rządowego. Tak jest w Bułgarii, Estonii, Grecji, Luksemburgu, Polsce, Portugalii, Rumunii, a także na Cyprze, Litwie i Słowacji. Potwierdza to wielokrotnie formułowane wnioski, że zdecydowanie słabszymi pod względem innowacyjności są kraje, które do struktur unijnych przystapiły w 2004 r. Natomiast dużym zaskoczeniem jest tutaj obecność Luksemburga, który w międzynarodowych rankingach innowacyjności plasuje się w ścisłej czołówce (zarówno według SII, jak i GII - 6 pozycja w rankingu). Oznacza to, że w przypadku oceny syntetycznej wartość pojedynczego czynnika może zostać zniwelowana poprzez znacząco wyższe wartości pozostałych zmiennych uwzględnionych w budowie miernika. Potwierdza to również przykład Słowenii, która może się poszczycić najwyższym w całej UE udziałem sektora przedsiębiorstw w wydatkach ogółem na $\mathrm{B}+\mathrm{R}(68,4 \%)$. Niemniej jednak, chociaż spośród nowych państw członkowskich w rankingach zajmuje ona najlepsze miejsca, to nadal jest tylko 16 pozycja według GII oraz 12 według SII. Przekraczający średnią unijną $(55,3 \%)$ udział sektora przedsiębiorstw w finansowaniu sfery badawczo-rozwojowej ma jeszcze tylko 5 krajów: Belgia, Dania, Francja, Niemcy i Szwecja. W przypadku dwóch ostatnich udział sektora biznesowego w nakładach ogółem przekracza $60 \%$.

Na potrzeby analizy porównawczej w zakresie zatrudnienia w obszarze badań i rozwoju przyjęta została linia demarkacyjna wyznaczona przez wartość średnią dla UE-28. Przeciętnie w Unii Europejskiej udział zatrudnienia w sferze B+R do zatrudnienia ogółem w sektorze przedsiębiorstw przewyższa zatrudnienie kadry badawczej w sektorze rządowym o ponad 300\%. Liderami w tym zakresie są

34 Szczegóły - patrz Eurostat Gross domestic expenditure on $R \& D$ (GERD) by source of funds $\%$ of total GERD. 
Irlandia, Malta, Dania oraz Wielka Brytania. Tutaj udział zatrudnienia w sferze badawczo-rozwojowej w sektorze przedsiębiorstw jest co najmniej 10-krotnie wyższy aniżeli w sektorze rządowym, w przypadku Irlandii i Malty nawet 20-krotnie. Z drugiej strony jest zdecydowanie liczniejsza grupa państw, które znajduja się poniżej linii demarkacyjnej. Ponadto, są również takie kraje, w których udział zatrudnienia kadry $\mathrm{B}+\mathrm{R}$ w sektorze przedsiębiorstw, jako procent $\mathrm{z}$ zatrudnienia ogółem, jest niższy niż w sektorze rządowym. Taka sytuacja ma miejsce w Bułgarii, Chorwacji, na Cyprze, w Grecji i Rumunii. Niska intensywność zatrudnienia kadry $\mathrm{B}+\mathrm{R}$ w sektorze prywatnym obserwowana jest również na Litwie, Łotwie oraz w Polsce i Słowacji. Szczegółowe dane zawiera tabela 7.

TABELA 7: Porównanie zatrudnienia kadry $B+R w$ sektorze rzadowym i przedsiębiorstw $w U E$ w roku 2013*

\begin{tabular}{|l|l|l|r|l|l|l|r|}
\hline \multicolumn{1}{|c|}{ Obszar } & $\begin{array}{c}\text { Sektor } \\
\text { przedsię- } \\
\text { biorstw }\end{array}$ & $\begin{array}{c}\text { Sektor } \\
\text { rządowy }\end{array}$ & Stosunek & Obszar & $\begin{array}{c}\text { Sektor } \\
\text { przedsię- } \\
\text { biorstw }\end{array}$ & $\begin{array}{c}\text { Sektor } \\
\text { rządowy }\end{array}$ & Stosunek \\
\hline UE-28 & 0,9037 & 0,2189 & $412,8 \%$ & \multicolumn{5}{|l|}{} \\
\hline Austria & 1,6208 & 0,1546 & $\mathbf{1 0 4 8 , 4 \%}$ & Litwa & 0,2733 & 0,2191 & $\mathbf{1 2 4 , 7 \%}$ \\
\hline Belgia & 1,1258 & 0,1468 & $\mathbf{7 6 6 , 9 \%}$ & Luksemburg & 1,4805 & 0,5555 & $266,5 \%$ \\
\hline Bułgaria & 0,1572 & 0,3194 & $\mathbf{4 9 , 2 \%}$ & Łotwa & 0,2078 & 0,184 & $\mathbf{1 1 2 , 9 \%}$ \\
\hline Chorwacja & 0,2013 & 0,3123 & $\mathbf{6 4 , 5 \%}$ & Malta & 0,5913 & 0,0277 & $\mathbf{2 1 3 4 , 7 \%}$ \\
\hline Cypr & 0,1286 & 0,1443 & $\mathbf{8 9 , 1 \%}$ & Niemcy & 1,0572 & 0,3012 & $351,0 \%$ \\
\hline Czechy & 0,9345 & 0,3088 & $302,6 \%$ & Polska & 0,2481 & 0,1775 & $\mathbf{1 3 9 , 8 \%}$ \\
\hline Dania & 1,694 & 0,1073 & $\mathbf{1 5 7 8 , 8 \%}$ & Portugalia & 0,7994 & 0,1329 & $\mathbf{6 0 1 , 5 \%}$ \\
\hline Estonia & 0,4635 & 0,191 & $\mathbf{2 4 2 , 7 \%}$ & Rumunia & 0,1408 & 0,1585 & $\mathbf{8 8 , 8 \%}$ \\
\hline Finlandia & 1,7008 & 0,3372 & $\mathbf{5 0 4 , 4 \%}$ & Słowacja & 0,2109 & 0,1897 & $\mathbf{1 1 1 , 2 \%}$ \\
\hline Francja & 1,3278 & 0,2009 & $\mathbf{6 6 0 , 9 \%}$ & Słowenia & 1,435 & 0,3399 & $\mathbf{4 2 2 , 2 \%}$ \\
\hline Grecja & 0,3015 & 0,4875 & $\mathbf{6 1 , 8 \%}$ & Szwecja & 1,4424 & 0,2709 & $\mathbf{5 3 2 , 4 \%}$ \\
\hline Hiszpania & 0,7535 & 0,3157 & $238,7 \%$ & Węgry & 0,6688 & 0,2412 & $277,3 \%$ \\
\hline Holandia & 1,6053 & 0,2161 & $\mathbf{7 4 2 , 9 \%}$ & Wielka Brytania & 0,798 & 0,0627 & $\mathbf{1 2 7 2 , 7 \%}$ \\
\hline Irlandia & 1,3559 & 0,0559 & $\mathbf{2 4 2 5 , 6 \%}$ & Włochy & 0,7866 & 0,2357 & $333,7 \%$ \\
\hline
\end{tabular}

* Analiza została przeprowadzona na podstawie danych dla roku 2013, w przypadku danych dla roku 2014 występowały znaczące braki danych.

Źr ódło: opracowanie własne na podstawie Eurostat; Total R\&D personnel and researchers by sectors of performance, as \% of total labour force and total employment, and by sex [rd_p_perslf]; stan na 02.12.2016 r. 


\section{Zakończenie}

Przedmiotem szczególnego zainteresowania ekonomistów w ostatnich latach są czynniki kształtujące rozwój innowacji z punktu widzenia ich wpływu na długookresowy rozwój gospodarczy i tym samym wzrost dobrobytu społecznego. Podkreśla się, że aktywność innowacyjna nie jest działaniem autonomicznym, a zależy od wielu czynników związanych z obszarem edukacji, wiedzy oraz działalnością badawczo-rozwojową. Wyzwania współczesnego świata, w tym, między innymi, postępujące procesy starzenia się społeczeństw, ujawniający się spadek poparcia dla procesów globalizacyjnych, budowanie zrównoważonej gospodarki sprzyjają rosnącemu zapotrzebowaniu na prowadzenie specjalistycznych badań i analiz eksperckich. W tym kontekście, wnikliwe i rzetelne omówienie procesów innowacyjnych, zarówno przedsiębiorstw, jak i gospodarek, znajduje się w kręgu odrębnych zainteresowań, przedstawiających w rzetelny sposób innowacyjność, szczególnie przedsiębiorstw i gospodarek narodowych.

Badania empiryczne koncentrują się na pomiarze innowacyjności, gdyż to ona w dużej mierze decyduje o tempie wzrostu gospodarczego. Innowacje są niezbędne do osiagania wyższej efektywności produkcji, a w efekcie do jej szybszego wzrostu i pełniejszego zaspokojenia potrzeb społecznych. Powszechne jest przekonanie o konieczności lepszego powiązania badań naukowych z praktyka, co powinno skutkować konkurencyjnymi produktami, które z kolei poprawiają konkurencyjność gospodarek na rynku międzynarodowym.

Znaczącym problemem badań, których celem jest ocena innowacyjności gospodarek oraz identyfikacja czynników determinujących jej poziom, jest szeroki zakres definiowalności tego zjawiska. Istnieje wiele różnorodnych wskaźników, za pomocą których można ją prezentować. Obejmują one ilościowo szeroki zakres zagadnień społeczno-ekonomicznych, które przez zgodność z obowiązującymi teoriami ekonomicznymi mają świadczyć o poziomie innowacyjności. Współcześnie akcentuje się wielowymiarowość zjawiska innowacyjności, a w badaniach, których celem jest zbudowanie międzynarodowych rankingów poziomu innowacyjności, poszczególne kraje są oceniane i analizowane w zakresie kilkudziesięciu cech. Wskaźniki syntetyczne pozwalają ocenić innowacyjność zarówno od strony nakładów, jak i efektów działalności innowacyjnej.

W niniejszym opracowaniu innowacyjność krajów UE oceniono w oparciu o wyniki międzynarodowych wskaźników syntetycznych, europejskiego - Summary Innovation Index oraz ogólnoświatowego - Global Innovation Index.

Zestawienie poziomu sumarycznego wskaźnika innowacyjności z tempem jego wzrostu wykorzystywane jest w raportach Innovation Union Scoreboard 
do klasyfikowania krajów Unii Europejskiej z punktu widzenia ich osiagnięć w zakresie innowacji. W tej klasyfikacji są cztery grupy krajów:

- liderów innowacyjności (Szwecja, Dania, Finlandia, Niemcy);

- podążających za liderami innowacyjności (Holandia, Luksemburg, Wielka Brytania, Irlandia, Belgia, Francja, Austria, Słowenia);

- umiarkowanych innowatorów (Estonia, Czechy, Cypr, Włochy, Portugalia, Malta, Hiszpania, Węgry, Grecja, Słowacja, Chorwacja, Polska, Litwa);

- skromnych innowatorów (Łotwa, Bułgaria, Rumunia).

Pozycja polskiej gospodarki nie może napawać optymizmem, gdyż Polska z wartością wskaźnika 0,313 zajmuje piąte miejsce od końca i wyprzedza tylko kraje o bardzo niskim poziomie innowacyjności, tj. Litwę, Lotwę, Bułgarię i Rumunię. Warto zauważyć, że wiele krajów o podobnej przeszłości historycznej do Polski, jak Czechy, Węgry czy Słowacja osiągają lepsze wyniki pod względem innowacyjności. Przyczyn takiej sytuacji można się doszukiwać w odniesieniu do większości wskaźników użytych w SII oraz w błędach organizacyjnych i gorszym stanie gospodarki.

W świetle rankingu GII najbardziej innowacyjnym krajem świata jest Szwajcaria, ale warto zauważyć, że w pierwszej dziesiątce znalazło się aż 7 krajów UE. Wysokie miejsca w rankingu zajmują również USA (5 miejsce) oraz Singapur (7 miejsce).

Rankingi innowacyjności SII i GII stanowią cenne źródło informacji, zwłaszcza w porównaniach międzynarodowych. Ocena poziomu innowacyjności pomiędzy poszczególnymi gospodarkami bez syntetycznych mierników byłaby niemożliwa. Ujęcie syntetyczne pozwala również na ukazanie miejsca wybranej gospodarki na tle pozostałych krajów i określenie dystansu wobec najbardziej innowacyjnych gospodarek świata. Jednak chcąc wskazać i zdiagnozować przyczyny niskiego poziomu innowacyjności wybranego kraju, nie można poprzestać na syntetycznej ocenie. Należy zwrócić uwagę przede wszystkim na kategorie, które przez ekonomistów są traktowane jako determinanty innowacyjności. Kategoriami tymi są nakłady na B+R w \% PKB, struktura tych nakładów oraz zatrudnienie $\mathrm{w}$ działalności badawczo-rozwojowej.

Z przeprowadzonych rozważań wynika, że poprawa innowacyjności gospodarek narodowych wymaga większego zaangażowania sektora prywatnego w finansowanie działalności badawczo-rozwojowej. Wprawdzie w ostatnich latach zaobserwowano pozytywne zmiany, w tym zakresie w większości krajów UE, ale nadal skala tych zmian nie jest wystarczająca. Ciaggle liczną grupę stanowią kraje, w których dominująca część nakładów na $\mathrm{B}+\mathrm{R}$ pochodzi z sektora rządo- 
wego. Tak jest niestety w Polsce oraz w Bułgarii, Estonii, Grecji, Luksemburgu, Portugalii, Rumunii, a także na Cyprze, Litwie i Słowacji.

Analizując zatrudnienie kadry $\mathrm{B}+\mathrm{R}$ w sektorze rządowym i przedsiębiorstw w krajach UE, zauważamy niską intensywność zatrudnienia kadry B+R w sektorze prywatnym na Litwie, Łotwie oraz w Polsce i Słowacji. NSI w Polsce i w większości krajów Europy Środkowo-Wschodniej nie odpowiadają standardom europejskim - ich efektywność, jak wynika z przeprowadzonej analizy, nie wskazuje na możliwości rozwoju.

\section{Bibliografia}

Banach Benedykt, Rozwój i postęp techniczny na tle ogólnych prawidłowości gospodarczych i cywilizacyjnych: wybrane problemy, Księgarnia Akademicka, Kraków 2010.

Beyer Karolina, Funkcjonowanie przedsiębiorstw w gospodarce opartej na wiedzy, w: Nierówności społeczne a wzrost gospodarczy, z. 35, Wydawnictwo Uniwersytetu Rzeszowskiego, Rzeszów 2013.

Dąbrowa Maria, Czy gospodarka w Polsce jest innowacyjna?, Zeszyty Naukowe Małopolskiej Wyższej Szkoły Ekonomicznej w Tarnowie 2014/24/1.

Drucker Peter F., Natchnienie i fart, czyli innowacje i przedsiębiorczość, Studio Emka, Warszawa 2004, s. 161.

Drucker Peter F., Innovation and Entrepreneurship, Harper and Row, New York 1985, s. 13, za: Stefan Kwiatkowski, Społeczeństwo innowacyjne, PWN, Warszawa 1990, s. 14.

Freeman Christopher, The Economics of Industrial Innovation, F. Pinter, London 1982.

Freeman Christopher, Technology and Economic Performance: Lessons From Japan, Printer Publisher, London 1987.

Gomułka Stanisław, Teoria innowacji $i$ wzrostu gospodarczego, Centrum Analiz Społeczno-Ekonomicznych, Warszawa 1998.

Hollanders Hugo, Tarantola Stefano, Innovation Union Scoreboard 2010 - Methodology report, Pro Inno Europe, 2011.

Grzelak Maria M., Innowacyjność przemystu spożywczego w Polsce. Ocena. Uwarunkowania. Rozwój, Wydawnictwo Uniwersytetu Łódzkiego, Łódź 2011.

Innovation Policy in a Knowledge-Based Economy, OECD, Paris 2002.

Janasz Władysław (red.), Innowacje w zrównoważonym rozwoju organizacji, Difin, Warszawa 2011.

Jewkes John, Sawers David, Stillerman Robert, The sources of invention, Macmillan, London 1958, za: Stanisław Gomułka, Teoria innowacji i wzrostu gospodarczego, Centrum Analiz Społeczno-Ekonomicznych, Warszawa 1998.

Lacny Kamil, Janczar-Smuga Małgorzata, Postęp techniczny i technologiczny w produkcji sto$d u$, Nauki Inżynierskie i Technologie 2013/4 (11).

Niedbalska Grażyna, Innowacje i transfer technologii. Słownik pojęć, Krzysztof B. Matusiak (red.), Polska Agencja Rozwoju Przedsiębiorczości, Warszawa 2011.

Niedzielska Elżbieta (red.), Technologia przetwarzania danych, Państwowe Wydawnictwo Ekonomiczne, Warszawa 1990. 
Okoń-Horodyńska Ewa, Państwo narodowe a proces globalizacji, Wydawnictwo Akademii Ekonomicznej w Katowicach, Katowice 1998.

Polityka innowacyjności, Dokument informacyjny o Unii Europejskiej, Parlament Europejski, s. 4, 2016, http://www.europarl.europa.eu/ftu/pdf/pl/FTU_5.9.7.pdf

Research and development expenditure, by sectors of performance, \% of GDP, Business sector and government sector, Eurostat; stan na 2.12.2016 r.

Schumpeter Joseph A., Teoria rozwoju gospodarczego, PWN, Warszawa 1960, s. 103-104.

Summary Innovation Index 2014, Summary Innovation Index 2010, por. European Commission, Innovation Union Scoreboard 2015, Internal Market Industry, Entrepreneurship and SMEs, Belgium 2015, http://ec.europa.eu/growth/industry/innovation/facts-figures/scoreboards/index_en.htm

Toffler Alvin, Trzecia fala, PIW, Warszawa 1985, s. 229, 436-437.

The Global Innovation Index 2015. Effective Innovation Policies for Development, Fontainebleau, Ithaca, and Geneva 2015, s. 9, https:/www.globalinnovationindex.org/userfiles/file/reportpdf/gii-full-report-2015-v6.pdf

Wandelt Klaus, Studia nad postępem technicznym i organizacyjnym, Poznańskie Towarzystwo Przyjaciół Nauk, Poznań 1972, s. 28, za: Stefan Kwiatkowski, Przedsiębiorczość intelektualna, Wydawnictwo Naukowe PWN, Warszawa 2000, s. 53.

Woroniecki Jan, Nowa gospodarka: miraż czy rzeczywistość? Doktryna - Praktyka - Optyka OECD, w: Władysław Welfe (red.), Społeczeństwo oparte na wiedzy, Społeczna Wyższa Szkoła Przedsiębiorczości i Zarządzania w Łodzi, Łódź 2001.

Woźniak Michał G., Wzrost gospodarczy. Podstawy teoretyczne, Wydawnictwo Akademii Ekonomicznej w Krakowie, Kraków 2004.

\section{Strony internetowe}

http://encyklopedia.pwn.pl/haslo/wynalazek;3998913.html; stan na 19.03.2016 r.

http://encyklopedia.pwn.pl/haslo/postep-techniczny;3960893.html; stan na 25.03.2016 r.

http://www.pi.gov.pl/parp/chapter_96055.asp?soid=DA555BE3925A41B69D8B97226EA582F7; stan na 5.05.2016 r.

http://www.eustat.eus/documentos/datos/PI_metod/IUS_2010_Methodology_report_c.pdf; stan na $28.05 .2016 \mathrm{r}$.

Maria M. GRZELAK

Elżbieta ROSZKO-WÓJTOWICZ

\section{APPLICATION OF INTERNATIONAL SYNTHETIC MEASURES TO ASSESS INNOVATIVENESS OF EU MEMBER STATES}

( Sum mary)

In the recent years, the global economy has changed significantly, as it has transitioned from labour intensive industrialisation to knowledge intensive economy based on an advanced level of human capital and technological potential. In the era when application of telecommunication technologies is very common, knowledge is characterised by an intense rate of change, growing practical 
usage, as well as speed and ease of access. People, companies, and economies are forced to adapt to these changes in order to guarantee their further progress. The aim of the paper is to evaluate innovativeness of the EU member states using selected international ratings as a base, with a special emphasis placed on research and development. The work consists of four parts. The introduction is followed by section two where the most crucial theoretical concepts and definitions are discussed. Section three shows the classification of the EU countries in international innovation rankings, in particular the Innovation Union Scoreboard (IUS). This section also presents an empirical analysis based on the statistical data contained in international reports and available from Eurostat. The last part of the paper is a summary of the theoretical and empirical considerations. The statistical material presented in the paper is derived from the EU Statistical Office (Eurostat), the World Bank, and other studies on innovativeness (IUS, EIS, GII). The conducted research has confirmed that greater participation of the business sector in financing $R \& D$ activities is required in order to improve innovative performance of an economy. Although some positive changes were observed in this area in a great number of the EU countries, still the scale of these changes is inadequate to the market demand.

Keywords: innovativeness; European Union; Summary Innovation Index; Global Innovation Index; synthetic measure 